\title{
Evaluasi Hasil Belajar Siswa Sekolah Menengah Atas Dengan Menggunakan Web
}

\author{
Wan Akbar Arramadhan Daulay \\ Program Studi Sistem Informasi, Fakultas Sains dan Teknologi, UINSU \\ Email : daulayakbar3@gmail.com
}

\begin{abstract}
Abstrak
Evaluasi dalam siklus pembelajaran signifikan, sehingga penggunaan penyusunan informasi bernilai signifikan mendapat salah satu kolom signifikan. Penanganan informasi bernilai bagus mendapatkan rapor hasil penilaian sangat layak, selagi penyiapan informasi bernilai signifikan akan dimanfaatkan semacam pencapaian siswa mengikuti pelatihan di tempat belajar. Untuk mendapatkan konsekuensi dari penanganan informasi yang bernilai tinggi, salah satunya adalah dengan menggunakan dan menciptakan inovasi seperti yang sekarang atau seluruhnya membuat kerangka kerja penyiapan harga informasi mekanis untuk berbasis situs situasi ini, meskipun hasil yang didapat dari penanganan informasi yang lebih tepat, Menggunakan sistem elektronik berbasis situs juga bisa berfungsi dengan pameran dewan kependidikan yang mengawasi hasil nilai siswa.
\end{abstract}

Motivasi paling utama dibalik pengungkapan " Perancangan Sistem Informasi Pengolahan Data Nilai Mahasiswa Berbasis Web Pada Sekolah SMK. Dengan adanya kerangka data ini maka diperlukan kerjasama baik dengan instruktur mata pelajaran, wali kelas maupun pertemuan terkait dalam penyusunan arsip evaluasi siswa secara lincah dan efektif.

\section{Kata Kunci}

Informasi sistem, informasi system desain, Situs, Sekolah, Sekolah SMK

\section{Pendahuluan}


Pembelajaran menilai signifikan, sehingga dalam penerapannya penanganan informasi harga diri merupakan salah satu kolom yang signifikan. Penanganan informasi yang bernilai besar akan menghasilkan raport karena penilaian yang baik, selain itu konsekuensi dari penyusunan informasi yang bernilai penting akan digunakan sebagai proporsi pencapaian siswa dalam pembelajaran di sekolah.

Untuk mendapatkan hasil dari penyiapan informasi yang sangat bermanfaat, salah satunya adalah dengan menggunakan inovasi yang ada dan saat ini sedang membuat atau seluruhnya membuat kerangka kerja penanganan informasi mekanik untuk skor siswa untuk situasi ini berbasis situs, meskipun hasil yang diperoleh dari penanganan informasi tersebut. mengukur semua dengan lebih tepat. Memanfaatkan kerangka kerja mekanis berbasis situs juga dapat memudahkan dewan pengajar untuk mengawasi informasi kelas siswa di sekolah.

Motivasi mendasar dibalik pengungkapan "Perencanaan Sistem Informasi Pengolahan Data Nilai Siswa Berbasis Web di SMK”. Dengan kerangka data ini, dipercaya dapat bekerja dengan pendidik pelajaran, pembimbing dan pertemuan tercatum merencanakan laporan ujian siswa secara aktif dan produktif. Penyusunan semacam ini muncul dalam sebuah "Sistem Informasi Elektronik untuk Menilai Hasil Belajar Siswa Sekolah SMK" yang beralasan bahwa "komputerisasi dapat meningkatkan jalan menuju evaluasi hasil belajar siswa yang diselesaikan oleh instruktur atau pendidik, khususnya dalam estimasi harga diri, waktu rekap harga, dan umur laporan ". Kemudian kerangka justifikasi data elektronik yang digunakan dalam penyusunan informasi harga juga diungkapkan oleh Suryandani et al. (2017: 72) "Penjelasan kerangka data online yang digunakan adalah kemudahan mengaksesnya, terutama dengan mengaksesnya melalui program di PC atau gadget ponsel".

\section{Studi Literatur}


Eksplorasi semacam ini adalah studi menulis. Teknik pembelajaran menulis merupakan rangkaian latihan yang diidentifikasikan dengan strategi pengumpulan informasi perpustakaan, membaca dan mencatat, serta mengawasi materi penelitian (Zed, 2008: 3).

\section{Metode Penelitian}

A. Metode perkembangan software

Beliau menjelaskan pengembanagan software yaitu prototype. prototype bisa di pakai untuk menyelesaikan kesalahpahaman:

1. Mendengarkan Pelanggan (Investigasi Kebutuhan Pemrograman)

Pada tahap ini pencipta memecah kerangka kerja penyusunan informasi bernilai yang berjalan di SMK. Khususnya: login harus diselesaikan oleh (staf TU, wali kelas dan instruktur mata pelajaran). Staf TU dapat menambahkan perubahan dan penghapusan (informasi instruktur, informasi kelas, informasi wali kelas, informasi siswa dan informasi subjek) dan dapat melihat laporan nilai dan mencetaknya. Wali kelas dapat melihat informasi siswa, melihat daftar skor siswa dan membuat leger kelas. Guru Mata Pelajaran dapat menambah, mengubah dan menghapus nilai siswa (hari demi hari, UTS dan UAS) dan membuat daftar nilai siswa.

\section{Buat atau perbaiki Mock-up}

Seperti yang diindikasikan oleh Sukamto dan Shalahuddin (2015: 32) "Model adalah sesuatu yang digunakan sebagai model perencanaan yang digunakan untuk mendidik, menunjukkan, menilai rencana, memajukan, atau tujuan yang berbeda". Pada tahap ini pencipta menggunakan aplikasi Adobe Dreamweaver CS5, Xampp, Jquery, dan Adobe Photoshop CS5 untuk membangun atau memperbaiki model framework penanganan informasi yang layak.

3. Klien melihat atau menguji Mock-up

Pada tahap ini pencipta mencoba model framework penanganan informasi bernilai yang telah 
dibuat dengan memanfaatkan User Acceptance Test (UAT). Demikian juga hasil untuk sekolah SMK, jika sudah sesuai persyaratan.

\section{B. Teknik Pengumpulan Data}

Data yang diperkenalkan dalam makalah ini adalah hasil dari tindakan pencarian informasi yang dilakukan baik selama bekerja maupun di luar latihan. Secara mendalam, kami telah memimpin beberapa teknik pemeriksaan, termasuk:

1. Metode Persepsi (Pengamatan)

Pencipta menyebutkan fakta obyektif langsung di SMK untuk memperhatikan latihan yang terkait dengan masalah yang diambil. Konsekuensi dari persepsi ini akan dicatat dan dari efek samping persepsi ini kita dapat menemukan siklus dan latihan serta kekurangannya.

\section{Metode Pertemuan (Interview)}

Alasan pencipta memanfaatkan teknik pertemuan adalah untuk menemukan dan mengecek kebenaran data serta mendapatkan data yang lebih jelas dan eksplisit. Dalam teknik ini pencipta mengarahkan pertemuan dengan Bpk. Herman Hardiansyah, S.SI selaku Ketua Jurusan Teknik Jaringan Komputer Sekolah Vokasi.

\section{Penelitian Perpustakaan}

Sebagai metode untuk membantu penyusunan teori ini, pencipta mengarahkan studi penulisan dengan menggunakan referensi yang dapat diaplikasikan pada permasalahan yang diangkat.

\section{Hasil dan Pembahasan}

3.1 Tahapan Perancangan Sistem

3.1.1 Analisis Kebutuhan

\section{A. Persyaratan Klien}


Dalam kerangka data penanganan informasi kelas siswa ini terdapat 3 klien yang dapat saling berkolaborasi dalam kerangka iklim, yaitu: staf TU, wali kelas dan pendidik mata pelajaran. Ketiga klien tersebut memiliki kualitas kerjasama dengan berbagai framework dan memiliki kebutuhan data yang beragam, sebagai berikut:

\section{Situasi Kebutuhan Staf TU}

Sebuah. Pilih hak akses

b. Masuk

c. Awasi informasi individu

d. Mengawasi informasi kelas

e. Mengawasi informasi pengganti

f. Awasi informasi wali kelas

g. Awasi informasi subjek

h. Awasi informasi instruktur

I. Melihat dan mencetak laporan nilai

2. Skenario Kebutuhan Wali Kelas

Sebuah. Pilih hak akses

b. Masuk

c. Awasi informasi individu

d. Lihat informasi pengganti

e. Lihat daftar nilai siswa

f. Awasi kelas leger

3. Situasi Kebutuhan Guru Mata Pelajaran

Sebuah. Pilih hak akses

b. Masuk 
c. Awasi informasi individu

d. Awasi hari demi hari

e. Awasi harga diri

f. Awasi nilai uas

g. Mengawasi catatan nilai siswa

B. Persyaratan Kerangka

1. Klien harus memilih hak masuk seperti yang ditunjukkan oleh pekerjaan mereka sebelum masuk

2. Klien harus masuk agar memiliki opsi untuk masuk ke program elektronik ini dengan memasukkan nama pengguna dan kunci rahasia

3. Klien harus logout setelah selesai menggunakan program

4. Kerangka kerja menghitung harga habis, nilai normal, predikat dan positioning.

3.1.2 System Rancangan

A. Kasus Penggunaan Pengolahan Data

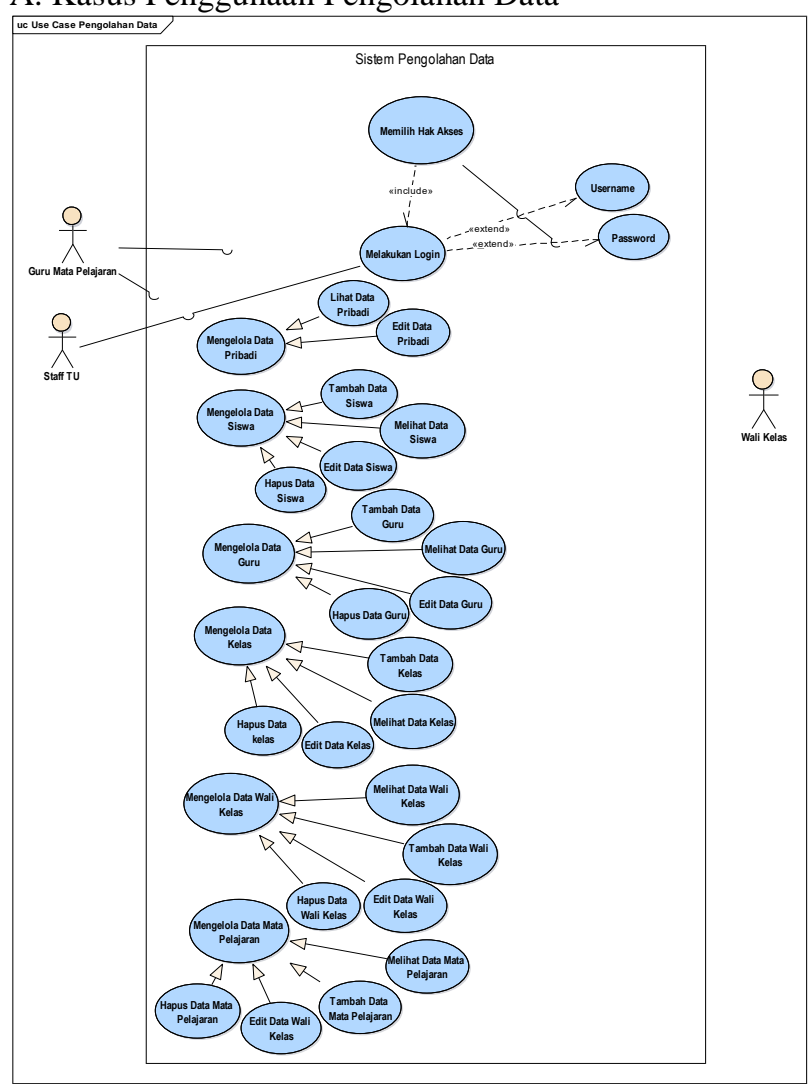


TABEL I

PEMILIHAN HAK AKSES

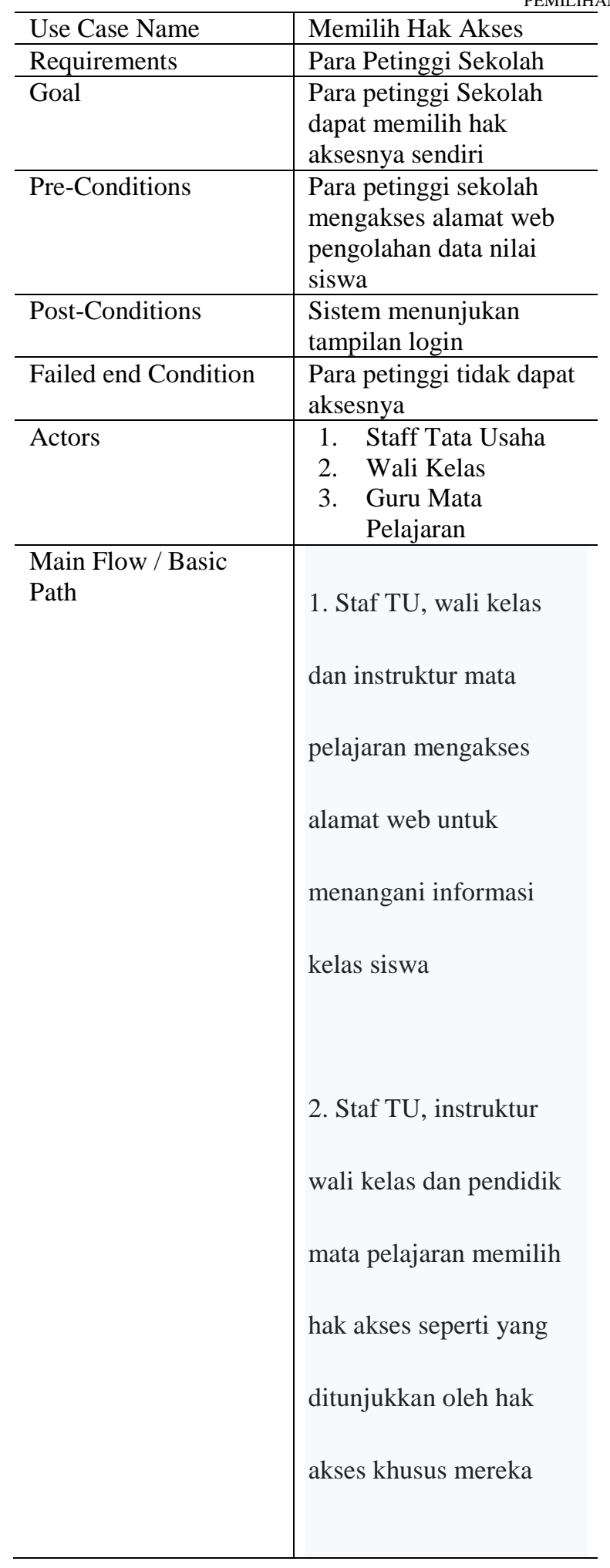




\begin{tabular}{|c|c|}
\hline & $\begin{array}{l}\text { Kerangka kerja } \\
\text { menunjukkan menu login } \\
\text { seperti yang ditunjukkan } \\
\text { oleh hak akses }\end{array}$ \\
\hline $\begin{array}{l}\text { Alternate } \\
\text { Flow/Invariant A }\end{array}$ & $\begin{array}{ll}\text { A1. } & \text { Sistem } \\
\text { menampilkan } \\
\text { kesalahan hak akses }\end{array}$ \\
\hline Invariant B & $\begin{array}{ll}\text { B1. } & \text { Para Petinggi } \\
\text { mengakses web } \\
\text { nilai rapot } \\
\text { B2. } \\
\text { Sistem } \\
\text { menampilkan pesan } \\
\text { "website sedang } \\
\text { tidak bisa diakses" }\end{array}$ \\
\hline
\end{tabular}

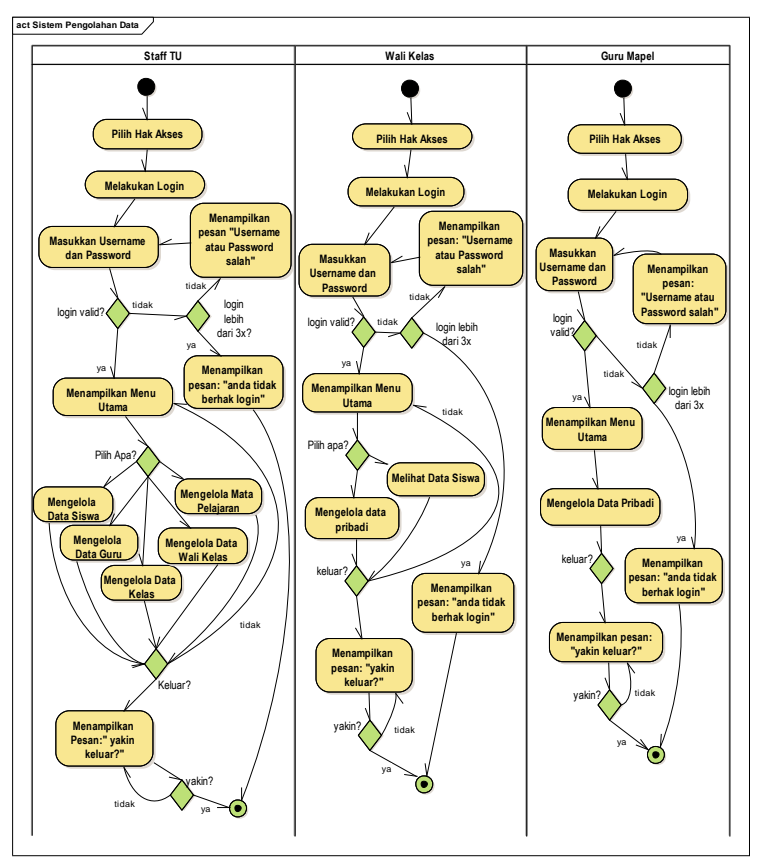

Gambar 2.Diagram Aktifitas Pengolahan Data

\subsubsection{Rancangan Prototype}

a. Interface Pilih Hak Akses Sistem Pengolahan Data Nilai Siswa 


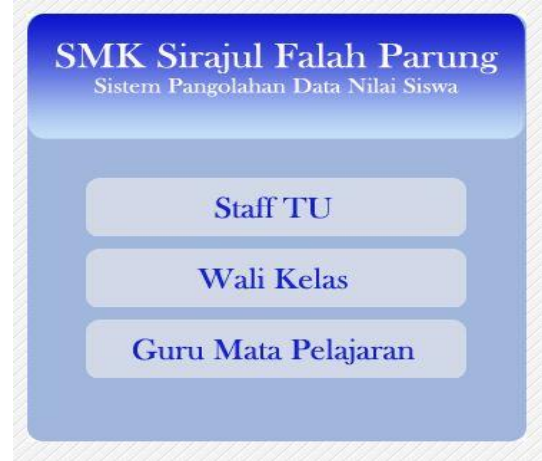

Gambar 3.Rancangan Tampilan Hak Akses

b.Interface Form Login Untuk Staff TU

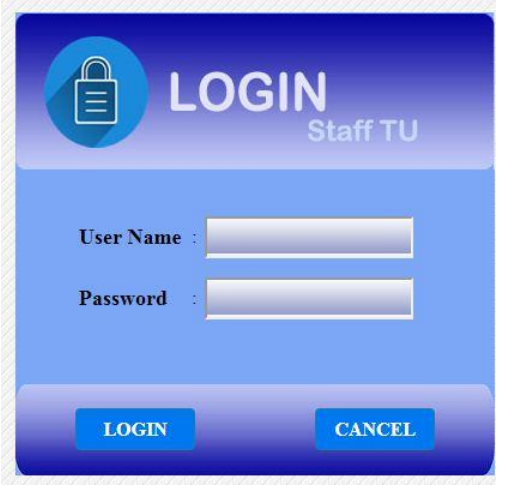

Gambar 4.Rancangan Tampilan Form Login Staff TU

c.Interface Menu Home Staff TU

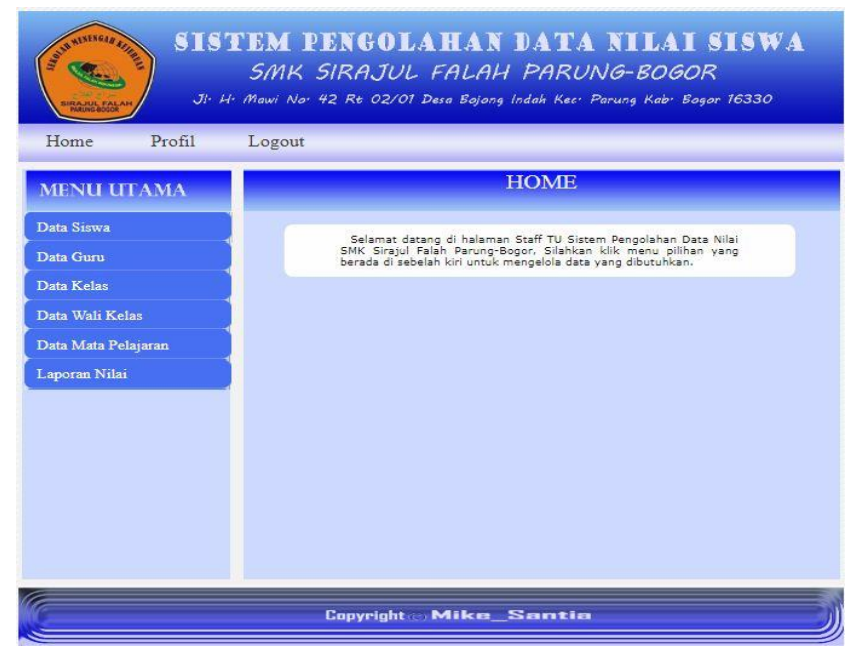

Gambar 5.Rancangan Tampilan Menu Home Staff TU

d.Interface Menu Home Data Siswa 


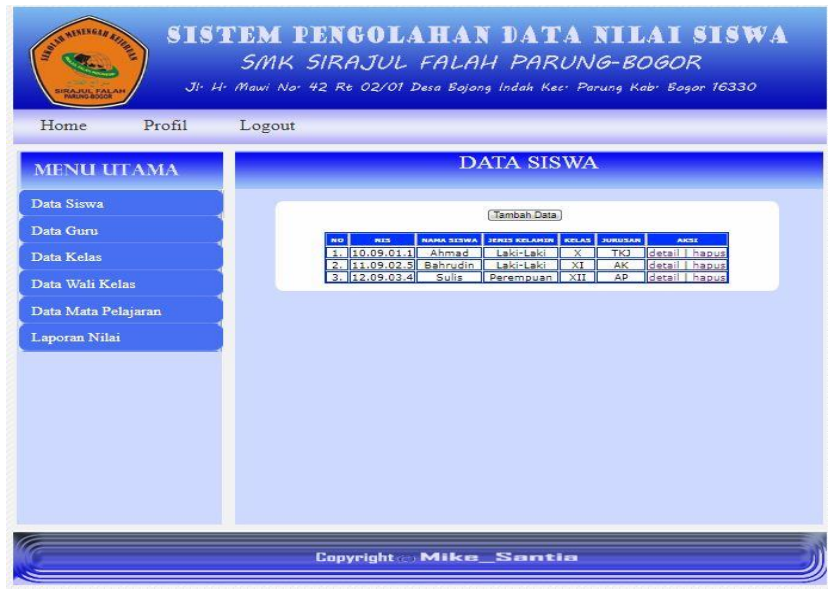

Gambar 6.Rancangan Tampilan Menu Data Siswa

\section{e.Interface Menu Home Data Guru}

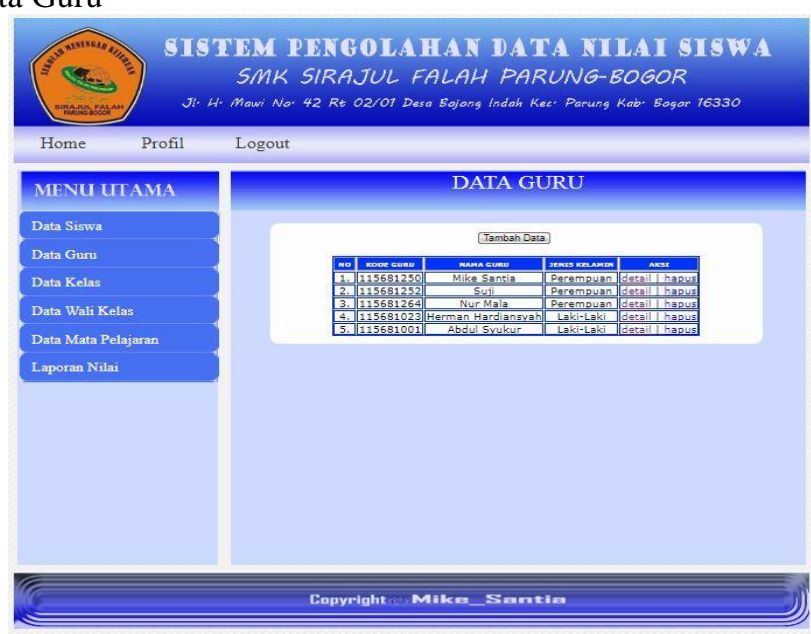

Gambar 7.Rancangan Tampilan Menu Data Guru

f.Rancangan ERD 


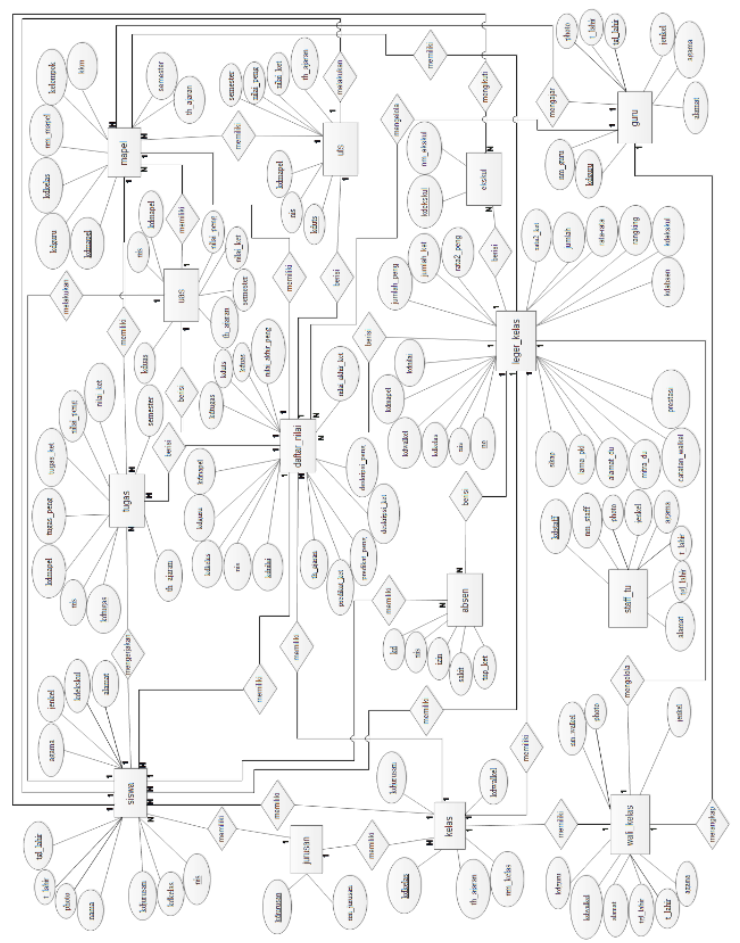

Gambar 8.Rancangan ERD

\section{g.Rancangan LRS}

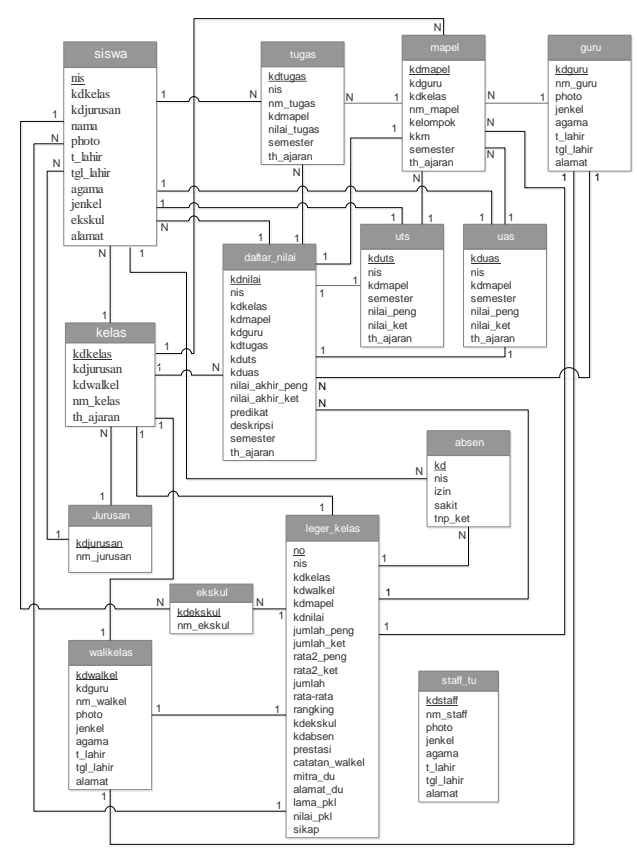

Gambar 9.Rancangan LRS 


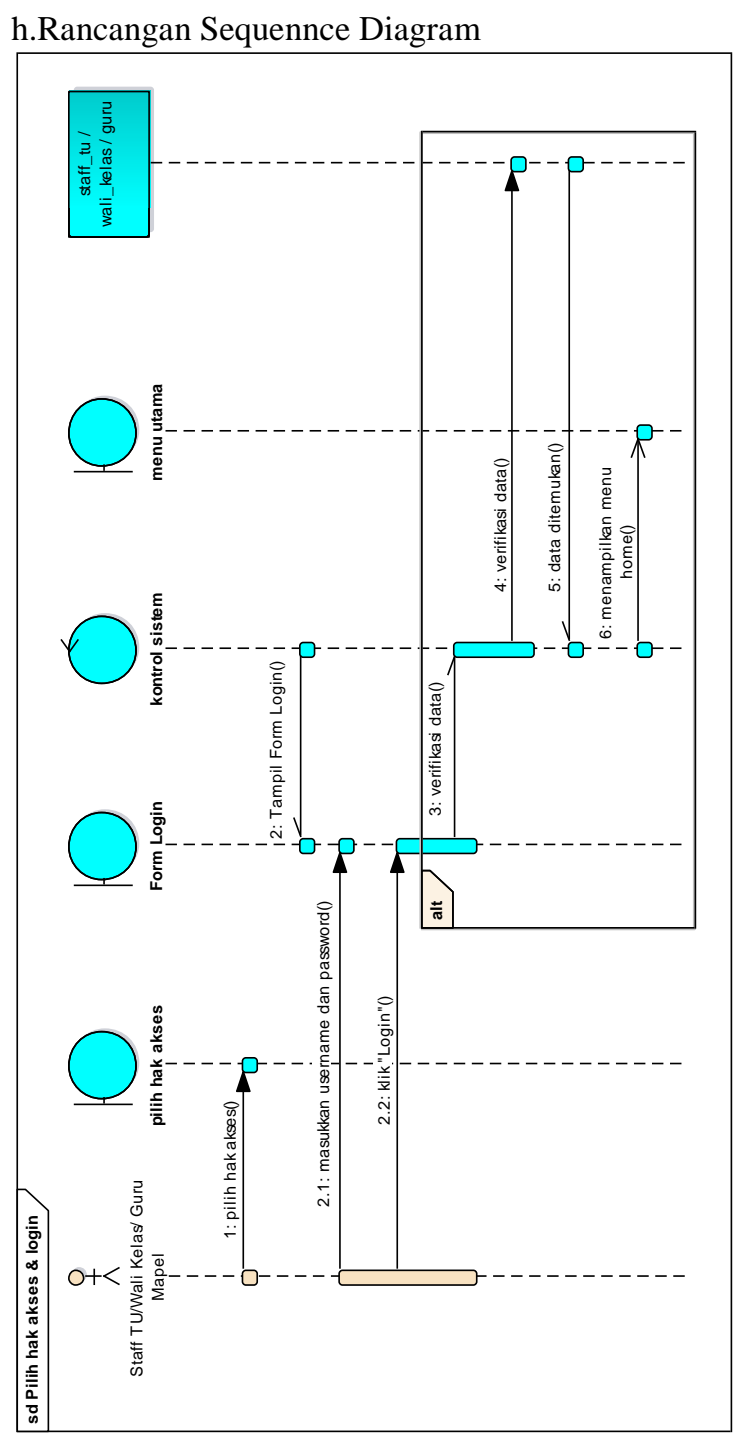

Gambar 10.Rancangan Sequence Diagram

\section{Kesimpulan}

Mengingat efek samping dari makalah ini, dapat disimpulkan bahwa:

1. Pemanfaatan kerangka data penyusunan informasi bernilai elektronik di SMK dapat memberikan penataan yang lebih cepat dalam pengawasan informasi nilai mahasiswa,

2. Lebih cepat melacak informasi kelas siswa yang diperlukan, 
3. Membuat laporan nilai siswa bisa lebih menarik dan mahir mengingat fakta bahwa penimbunan informasi sekarang ada dalam kumpulan data,

4. Untuk memanfaatkan kerangka kerja ini, klien harus memilih hak akses dan login terlebih dahulu

\section{Referensi}

1. Kaafi, A. Al, and Syahriani, "SISTEM INFORMASI PENJUALAN PAKAIAN BERBASIS WEB", in Konferensi Nasional Ilmu Sosial \& Teknologi (KNiST), 2016, p277-282.

2. Kostaman, N. and Sumaryana, Y,"APLIKASI PEMESANAN TIKET OTO BUS BUDIMAN BERBASIS ONLINE", Jurnal Manajemen Dan Teknik Informatika (JUMANTAK), Retrieved from http://jurnal.stmik-dci.ac.id/index.php/jumantaka/article/view/275/0

3. Lipursari, A,"Peran Sistem Informasi Manajemen (Sim) Dalam Pengambilan Keputusan”, JURNAL STIE SEMARANG, 5(1), 26-37. https://doi.org/2252-7826

4. Nursahid, Riasti, B. and Purnama, B,'Pembangunan sistem informasi penilaian hasil belajar siswa Sekolah Menengah Atas (SMA) Negeri 2 Rembang berbasis web" Ijns.Org, 4(2), 54-63. Retrieved from http://www.ijns.org/journal/index.php/ijns/article/view/1339

5. Suryandani, F., Basori, B. and Maryono, D., "ENGEMBANGAN SISTEM INFORMASI AKADEMIK BERBASIS WEB SEBAGAI SISTEM PENGOLAHAN NILAI SISWA DI SMK NEGERI 1 KUDUS", Jurnal Ilmiah Pendidikan Teknik Dan Kejuruan, 10(1), 71-82. https://doi.org/10.20961/jiptek.v10i1.14976

6. Sukamto, R. A., and Salahudin, M., REKAYASA PERANGKAT LUNAK. Bandung: Informatika, 2015

7. Susanti, M.,"PERANCANGAN SISTEM INFORMASI AKADEMIK BERBASIS WEB PADA SMK PASAR MINGGU JAKARTA", Jurnal Informatika, 3(1). https://doi.org/10.31311/JI.V3I1.304

8. Syafii, and Kusumawardani, H. H,"SISTEM INFORMASI PENGOLAHAN NILAI SISWA BERBASIS WEB PADA SMK MUHAMMADIYAH KARANGANYAR”,Jurnal Surya Informatika, 2(1).Retrieved from http://ejournal.politeknikmuhpkl.ac.id/index.php/surya_informatika/article/view/26

9. Widagdo, S., \& Kurnia, E. D., "NILAI PENDIDIKAN DALAM UPACARA TRADISI HAUL SEMANGKIN DI DESA MAYONG LOR KECAMATAN MAYONG KABUPATEN JEPARA" Journal.Unnes.Ac.Id, 37-47. Retrieved from http://journal.unnes.ac.id/nju/index.php/lingua/article/view/2978 